ISSN 2693-2504

\title{
Decoding of the Skin Sensations to the Low Intensive Electric and Magnetic Fields
}

\author{
Journal of Bioscience \& Biomedical Engineering
}

Research Article

\section{Dr. George Zdravkov, MD, DSc, Lac}

Center for Integrative Medicine

\section{*Correspondence author}

\author{
Dr. George Zdravkov \\ Center for Integrative Medicine \\ 340 W. Butterfield Rd \#3 \\ Elmhurst \\ IL 60126 \\ USA
}

Submitted : 12 Jan 2020 ; Published : 28 Jan 2021

\begin{abstract}
Summary
The article represents the ability of the human skin sensitive receptors and receptors of the proprioception to detect and code the very low intensive electric and magnetic fields. Was made the classification of the skin sensations to the electric field $(E F)$ and magnetic field $(M F)$ - 34 kind sensations. Was made the electrophysiology pattern of every one sensation to the electric field $(E F)$ and magnetic field $(M F)$ - how the skin sensitive receptors and receptors of proprioception code the electric and magnetic fields to be translate from the sensitive nerve to the brain.
\end{abstract}

\section{Introduction}

The human skin is the biggest organ at the human body with the isolating and protecting function from the environment. At same time it is the biggest sensitive organ, with the most numbers specialized sensory receptors and the touch is the oldest sensation at the living tissue evolution [1].

Within the neurophysiology, uses the contact method of examination of the four-base sensation - temperature sensation, touch, vibration and pain sensation $[1,2]$. There is not the broadly accepted methodology for the examination of the skin sensation to the electric and magnetic field.

In the article is presented the part of my research on the skin sensitivity to the electric and magnetic field, conducted for the past decades. Were used the electronic element with very small intensity of the electric and magnetic field which can be registered to the smallest changes at the neurophysiology parameters of the skin.

We hope the research will give the contribution to the creation of the methodology of examination of the skin sensitivity to the electric and magnetic field.

\section{Materials and Methodology}

The research work was conducted for 24 years, were examined 194 peoples, 148 women and 46 men, from 22 to 61 years old. All examinate persons had the professional psychiatric, psychologic and neurologic medical exam to rule out the pathology disorders of the central and peripheral nervous systems.

As the sources of EF and MF were used the electronic elements, see Table 1. To found the maximal response of the skin receptors to $\mathrm{EF}$ and MF from the electronic elements, the frequency and intensity of their working regime were gradually increased, from minimum to maximum. In the article are presented the calibration of the electronic elements, which produce the maximal reaction of the skin receptors emitted from the electric and magnetic fields (for example after the electrophysiology pattern of the pain will be present the graphics of the conducted experimental work for the electronic element Transistor D45H11 (PNP)). The intensity of the EF and $\mathrm{MF}$ were recorded on $1 \mathrm{~cm}$ distance from the electronic elements with Spectran NF - 5035, AARONIA AG, Germany, www.ELEKTROSMOG.DE, same distance on which was placed the top of the second finger of the examinate person. 


\begin{tabular}{|l|l|l|l|}
\hline ELECTRONIC ELEMENTS & CALIBRATION F [Hz] & ELECTRIC FIELD [V/m] & MAGNETIC FIELD [nT] \\
\hline Cap 51 F/630 V, nonelectrolyte & 39900 & 9.28 & 0 \\
\hline Cap 51 F/630 V, nonelectrolyte & 10400 & 9.16 & 0 \\
\hline $\begin{array}{l}\text { Cap 560 nF/630 V ceramic, } \\
\text { nonelectrolyte }\end{array}$ & 908 & 30.24 & 4.46 \\
\hline $\begin{array}{l}\text { Cap 560 nF/630 V ceramic, } \\
\text { nonelectrolyte }\end{array}$ & 6030 & 31.48 & 36.94 \\
\hline $\begin{array}{l}\text { Cap 560 nF/630 V ceramic, } \\
\text { nonelectrolyte }\end{array}$ & 4000 & 70.62 & 56.82 \\
\hline $\begin{array}{l}\text { Cap 560 nF/630 V ceramic, } \\
\text { nonelectrolyte }\end{array}$ & 5060 & 38.02 & 37.68 \\
\hline $\begin{array}{l}\text { Diod GP 30G } \\
\text { Diod GP 30G } 0.43\end{array}$ & 44800 & 7.88 & 0.13 \\
\hline $\begin{array}{l}\text { Coil with ferrite } \\
\Omega / 10 \mathrm{~W}\end{array}$ & 96600 & 4.91 & 0.208 \\
\hline $\begin{array}{l}\text { Coil with ferrite } \\
\Omega / 10 \mathrm{~W}\end{array}$ & 41800 & 66.42 & 1676 \\
\hline $\begin{array}{l}\text { Coil with ferrite } \\
\Omega / 10 \mathrm{~W}\end{array} \quad 0.43$ & 44200 & 78.32 & 24280 \\
\hline \begin{tabular}{l} 
Resistor 3.5 $\Omega / 15 \mathrm{~W}$ \\
\hline Transistor D45H11 (PNP)
\end{tabular} & 87800 & 630.8 \\
\hline
\end{tabular}

The verification of the skin sensations to EF and MF was done with the BIOPAC System 150 (University of California, USA). Were recorded the relative skin conductivity, skin temperature, goniometry of the finger movements and activity of the sensitive nerves - median and radial nerves [4].

The relative skin conductivity was recorded with the TSD sensor 203 consists of two $\mathrm{Ag}-\mathrm{AgCl}$, non-polarized electrodes mounted in individual ergonomic (for fingers) plastic holders that improve contact with the skin. Electrodes are attached to the fingers with Velcro strips. Electrodes have a $6 \mathrm{~mm}$ (diameter) contact interface with a $1.6 \mathrm{~mm}$ cavity for placement of the electrode gel (GEL 101). Each sensor has a length of $16 \mathrm{~mm}$, a width of $17 \mathrm{~mm}$, a height of $8 \mathrm{~mm}$, and weighs $4.5 \mathrm{~g}$. The GSR 100C amplifier measures the levels of skin conductance (skin conductivity level, SCL), as well as its change (skin conductivity response, SCR). GSR 100C uses a constant voltage technique for measuring conductivity. Thus, both absolute (SCL+SCR and relative (SCR) skin conductivity can be measured. The technical specifications of GSR 100C are: Gain: 20, 10, 5, 2 micro-mhos/volt; Output range: $\pm 10 \mathrm{~V}$ (analog); Low pass filter: $1 \mathrm{~Hz}, 10 \mathrm{~Hz}$; High pass filter: DC, $0.05 \mathrm{~Hz}, 0.5 \mathrm{~Hz}$; Sensitivity: 0.7 nano-mhos - with MP system; Excitation: Vex $=0.5$ VDC (Constant Voltage); Input Signal Range: Gain $20 \sim$ range ( $\mu$ mhos) $0-200,10 \sim 0-100,5 \sim$ $0-50,2 \sim 0-20$.)
The skin temperature was recorded with the sensor TSD $202 \mathrm{~A}$, which is very small (diameter $1.7 \mathrm{~mm}$, length $5 \mathrm{~mm}$ ) and is a quickly registering temperature sensor (response time: $0.6 \mathrm{sec}$ ). The technical specifications of the sensor TSD 202A are: Nominal resistance: $2252 \Omega @ 25$ o C; Maximum operating temperature: $60 \mathrm{o} \mathrm{C}$ (with STK 100C); Accuracy and Interchangeability: $\pm 0.2 \mathrm{o}$; ; Transducer Compatibility: YSI ${ }^{\circledR}$ 400 series temperature probes. The technical specifications of the amplifier SKT 100C are: Gain 5, 2, 1, 0.5 o F/Volt (which can be calibrated in o C/Volt); Output range: $\pm 10 \mathrm{~V}$ (analog); Low pass filter: $1 \mathrm{~Hz}, 10 \mathrm{~Hz}$; High pass filter: DC, $0.05 \mathrm{~Hz}, 0.5$ Hz; Sensitivity: 180 micro o F (100 micro o C); Input signal range: Gain $5 \sim$ Range (o C) 5-60, $2 \sim 22-43,1 \sim 27-37,0.5$ $\sim 30-35$.

The goniometry of the second finger of the examinate person was recorded with the Goniometer TSD 130E, which is used to register the joint motion in the finger of the hand (uniaxial goniometer, max length $35 \mathrm{~mm}$, min length $30 \mathrm{~mm}$, range $\pm 180 \mathrm{o}$, and weight $8 \mathrm{~g}$ ). It measures the change in distance between two points at a moving joint and attaches to the finger with adhesive medical tape TAPE2. TSD 130E has the following technical specifications: Nominal output $5 \mu \mathrm{V} /$ degree (normalized to $1 \mathrm{~V}$ excitation). DA 100C is a universal amplifier for a wide variety of sensors detecting pressure, force, displacement, thermocouple, piezo sensors, light sensors, 
microphones and more. The technical specifications for DA $100 \mathrm{C}$ are: Gain 50, 200, 1000, 5000; Output range: $\pm 10 \mathrm{~V}$ (analog); Low pass filter: $10 \mathrm{~Hz}, 300 \mathrm{~Hz}, 5000 \mathrm{~Hz}$; High pass filter: DC, $0,05 \mathrm{~Hz}$; Noise voltage: $0.11 \mu \mathrm{V} \mathrm{rms}-(0.05-10 \mathrm{~Hz})$; Temperature drift: $0.3 \mu \mathrm{V} /$ o C; $\mathrm{Z}$ (input): $2 \mathrm{M} \Omega$ (Differential); CMRR: $90 \mathrm{~dB} \min (50 / 60 \mathrm{~Hz})$; CMIV: $\pm 10 \mathrm{~V}$ (referenced to amplifier ground), \pm 1500 VDC (referenced to mains ground); Voltage reference: -10 to +10 infinitely adjustable @ 20 ma (max); Input voltage range: Gain $50 \sim$ Vin $(\mathrm{mV}) \pm 200,200 \sim$ $\pm 50,1000 \sim \pm 10,5000 \sim \pm 2$.

The activity of the peripheral nerve was recorded with the superficial neurography by the sensors EL 503, which are a pair of $\mathrm{Ag}-\mathrm{AgCl}$ adhesive electrodes, precoated with gel, highly chlorinated, for quick recording and single use. They have a diameter of $35 \mathrm{~mm}$ (with adhesive plastic strip) and are suitable for electrocardiography, electromyography, electroencephalography, and electro-ophtalmography. These electrodes are connected to the amplifier EEG 100C via sound isolated cables LEAD 110S-W and LEAD 110S-R. The amplifier $100 \mathrm{C}$ has the following technical specifications: Gain 5000, 10000, 20000, 50000; Output selection: normal, alpha wave indicator; Output range: $\pm 10 \mathrm{~V}$ (analog); Low pass filter: $35 \mathrm{~Hz}, 100 \mathrm{~Hz}$; High pass filter: $0.1 \mathrm{~Hz}, 1.0 \mathrm{~Hz}$; Notch filter: $50 \mathrm{~dB}$ rejection @ $50 / 60 \mathrm{~Hz}$, Noise voltage: $0.1 \mu \mathrm{V}$ rms - (0.1-35Hz); Z (input): $2 \mathrm{M} \Omega$ (Differential), $1000 \mathrm{M} \Omega$ (Common mode); CMRR: $110 \mathrm{~dB} \min (50 / 60 \mathrm{~Hz})$; CMIV: \pm 10 $\mathrm{V}$ (referenced to amplifier ground), $\pm 1500 \mathrm{VDC}$ (referenced to mains ground); Input voltage range: Gain $5000 \sim \operatorname{Vin}(\mathrm{mV}) \pm 2$, $10000 \sim \pm 1,20000 \sim \pm 0.5,50000 \sim \pm 0.2$.

The sensors of the temperature, goniometry and superficial neurography were placed on the second finger of the examinate person. The sensors for skin conductivity were attached to the third and five fingers.

The top of the second finger of the examinate person was fixed on $1 \mathrm{~cm}$ distance from the electronic element and $30 \mathrm{sec}$ record for every different electronic element and calibration. The records were performed in the isolated wood room, without windows, 74 degrees Fahrenheit temperature.

\section{Results}

From 194 examinate people, 37 had the same sensations to the same calibration of the same electronic elements. No matter, if they have or not have the sensations, the skin and sensitive peripheral nerves of the 194 examinate peoples responded of the same way to the EF and MF, emitted from the same electronic elements $(p<0.3)$. These repeated responds were classified as the electrophysiology pattern of the skin sensations to the EF and MF.

The sensations of the examinate persons to EF and MF were grouped in 7 major group.

\section{The classification of the skin sensations to the EF and MF} is:

\section{Thermal Sensations}

- Warm thermal sensations.

- Cold thermal sensations

Inductive Sensations

- Repelling (involuntary movement in direction out from the electronic element surface)

- Attractive (involuntary movement to the electronic element surface)

Vibrations (repeated involuntary movement to the electronic element surface)

- Single vibrations.

- Group vibrations.

- Constant vibrations.

- Depending on their amplitude, they can be divided into small and high amplitude vibrations.

- Depending on their frequency, they can be divided into low, medium and high frequency vibrations.

Involuntary movement (involuntary movement in 3D space around the electronic element)

- Single involuntary movement.

- Permanent involuntary movement.

- Involuntary movement with vibrations.

- Involuntary movement with inductive sensations.

- Involuntary movement caused by pricking sensations.

Pricking Sensations

- Single pricking sensations.

- Group pricking sensations.

- Constant pricking sensations.

- Weak pricking sensations.

- Strong pricking sensations.

- Pricking causing pain.

- Pricking causing pressing sensation

- Pricking causing inductive sensations.

- Pricking causing vibrations.

- Pricking causing involuntary movement.

- Depending on their amplitude, they are divided into small, medium, and high amplitude pricking

Pressing Sensations (sensation of the pressing of the finger from all directions)

- Weak pressing sensations.

- Strong pressing sensations.

Pain

- Slight pain.

- Strong pain.

- Pain caused by pricking sensations.

- Pain caused by pressing sensations.

- Pain caused by thermal sensations.

At the Table 2 are presented the electronic elements with the calibration, their electric and magnetic field on $1 \mathrm{~cm}$ distance from the elements, types sensations, which they induced at the skin receptors (in persons, which have sensations to EF and MF), maximal amplitudes of the impulses at the sensory nerves (medians and radialis nerves) and maximal amplitude and duration of the involuntary movement in the second finger`s joints. 


\begin{tabular}{|c|c|c|c|c|c|c|}
\hline $\begin{array}{l}\text { ELECTRONIC } \\
\text { ELEMENTS }\end{array}$ & $\begin{array}{l}\text { CALIBRATION } \\
\mathrm{F}[\mathrm{Hz}]\end{array}$ & $\begin{array}{l}\text { E L E C T R I C } \\
\text { FIELD }[\mathrm{V} / \mathrm{m}]\end{array}$ & $\begin{array}{l}\text { MAGNETIC } \\
\text { FIELD }[\mathrm{nT}]\end{array}$ & $\begin{array}{ll}\text { TYPE } & \text { OF } \\
\text { SENSTION } & \end{array}$ & $\begin{array}{l}\text { SENSORY NERVES } \\
\text { ACTIVITY Amplitude } \\
\text { [mV]Duration [s] } \\
\text { (channel 4) }\end{array}$ & $\begin{array}{l}\text { GONIOMETRY } \\
\text { Amplitude [deg] } \\
\text { Duration [s] } \\
\text { (channel 3) }\end{array}$ \\
\hline $\begin{array}{l}\text { Cap } 51 \mathrm{~F} / 630 \mathrm{~V} \text {, } \\
\text { nonelectrolyte }\end{array}$ & 32200 & 3.73 & 0 & $\begin{array}{l}\text { Thermal } \\
\text { sensation- cold } \\
\text { type }\end{array}$ & $\begin{array}{l}\text { Cold spindle } \\
\text { amplitude }-0.18 \mu \mathrm{V} ; \\
\text { Duration }-0.25 \mathrm{~s}\end{array}$ & $\begin{array}{l}\text { Max. amplitude - } \\
0.3 \mathrm{deg} \\
\text { Duration - } 0.14 \mathrm{~s}\end{array}$ \\
\hline $\begin{array}{l}\text { Cap } 51 \mathrm{~F} / 630 \mathrm{~V} \text {, } \\
\text { nonelectrolyte }\end{array}$ & 10400 & 9.16 & 0 & $\begin{array}{l}\text { Pricking } \\
\text { sensation - } \\
\text { Permanent type; } \\
\text { Vibration - } \\
\text { Single type }\end{array}$ & $\begin{array}{l}\text { Max. amplitude - } 140 \\
\mu \mathrm{V}\end{array}$ & $\begin{array}{l}\text { Max. amplitude - } \\
1.5 \mathrm{deg} \\
\text { Duration - } 0.8 \mathrm{~s}\end{array}$ \\
\hline $\begin{array}{l}\text { Cap } 51 \mathrm{~F} / 630 \mathrm{~V} \text {, } \\
\text { nonelectrolyte }\end{array}$ & 39900 & 306.6 & 2.48 & Pain sensation & $\begin{array}{l}\text { Min. amplitude }-4.3 \\
\mu \mathrm{V} \\
\mathrm{Max} . \text { amplitude }-46 \\
\mu \mathrm{V} \\
\text { Duration }-0.4 \mathrm{~s}\end{array}$ & $\begin{array}{l}\text { Max. amplitude - } \\
0.48 \mathrm{deg} \\
\text { Duration - } 1 \mathrm{~s}\end{array}$ \\
\hline $\begin{array}{l}\text { Cap } 560 \mathrm{nF} / 630 \\
\text { V ceramic, } \\
\text { nonelectrolyte }\end{array}$ & 908 & 30.24 & 4.46 & $\begin{array}{l}\text { Pressing } \\
\text { sensation }\end{array}$ & $\begin{array}{l}\text { Max. amplitude - } 40 \\
\mu \mathrm{V}\end{array}$ & $\begin{array}{l}\text { Max. amplitude - } \\
0.28 \text { deg } \\
\text { Duration }-0.26 \mathrm{~s}\end{array}$ \\
\hline $\begin{array}{l}\text { Cap } 560 \mathrm{nF} / 630 \\
\text { V ceramic, } \\
\text { nonelectrolyte }\end{array}$ & 6030 & 31.48 & 36.94 & $\begin{array}{l}\text { Inductive } \\
\text { sensation - } \\
\text { Attractive type }\end{array}$ & $\begin{array}{l}\text { Max. amplitude }-62 \\
\mu \mathrm{V}\end{array}$ & $\begin{array}{l}\text { Max. amplitude - } \\
3.3 \mathrm{deg} \\
\text { Duration- } 1.62 \mathrm{~s}\end{array}$ \\
\hline $\begin{array}{l}\text { Cap } 560 \mathrm{nF} / 630 \\
\text { V ceramic, } \\
\text { nonelectrolyte }\end{array}$ & 4000 & 70.62 & 56.82 & $\begin{array}{l}\text { Inductive } \\
\text { sensation - } \\
\text { Repelling type }\end{array}$ & $\begin{array}{l}\text { Max. amplitude - } 140 \\
\mu \mathrm{V}\end{array}$ & $\begin{array}{l}\text { Max. amplitude - } \\
5.2 \mathrm{deg} \\
\text { Duration - } 1.5 \mathrm{~s}\end{array}$ \\
\hline $\begin{array}{l}\text { Cap } 560 \mathrm{nF} / 630 \\
\text { V ceramic, } \\
\text { nonelectrolyte }\end{array}$ & 5060 & 38.02 & 37.68 & $\begin{array}{l}\text { Involuntary } \\
\text { movement - } \\
\text { Permanent type }\end{array}$ & $\begin{array}{l}\text { Max. amplitude - } 134 \\
\mu \mathrm{V}\end{array}$ & $\begin{array}{l}\text { Max. amplitude - } \\
4.9 \mathrm{deg} \\
\text { Duration - } 4.2 \mathrm{~s}\end{array}$ \\
\hline Diod GP 30G & 96600 & 7.88 & 0.13 & $\begin{array}{l}\text { Thermal } \\
\text { sensation- warm } \\
\text { type }\end{array}$ & $\begin{array}{l}\text { Warm spindle } \\
\text { amplitude }-0.66 \mu \mathrm{V} ; \\
\text { Duration }-0.42 \mathrm{~s}\end{array}$ & $\begin{array}{l}\text { Max. amplitude - } \\
0.4 \mathrm{deg} \\
\text { Duration - } 0.45 \mathrm{~s}\end{array}$ \\
\hline Diod GP 30G & 45030 & 7.36 & 0.128 & $\begin{array}{l}\text { Pricking } \\
\text { sensation - } \\
\text { Permanent type }\end{array}$ & $\begin{array}{l}\text { Max. amplitude }-1.28 \\
\mu \mathrm{V}\end{array}$ & $\begin{array}{l}\text { Max. amplitude - } \\
0.18 \mathrm{deg} \\
\text { Duration }-0.22 \mathrm{~s}\end{array}$ \\
\hline Diod GP 30G & 152800 & 4.91 & 0.208 & $\begin{array}{l}\text { Involuntary } \\
\text { movement - } \\
\text { Permanent type }\end{array}$ & $\begin{array}{l}\text { Max. amplitude }-2.24 \\
\mu \mathrm{V}\end{array}$ & $\begin{array}{l}\text { Max. amplitude - } \\
14.8 \mathrm{deg} \\
\text { Duration }-3.4 \mathrm{~s}\end{array}$ \\
\hline $\begin{array}{l}\text { Coil with ferrite } \\
0.43 \Omega / 10 \mathrm{~W}\end{array}$ & 44800 & 66.42 & 1676 & $\begin{array}{l}\text { Pricking } \\
\text { sensation - } \\
\text { Single type; } \\
\text { Involuntary } \\
\text { movement - } \\
\text { Permanent type }\end{array}$ & $\begin{array}{l}\text { Max. amplitude - } 225 \\
\mu \mathrm{V}\end{array}$ & $\begin{array}{l}\text { Max. amplitude - } \\
27 \text { deg } \\
\text { Duration - } 4.8 \mathrm{~s}\end{array}$ \\
\hline $\begin{array}{l}\text { Coil with ferrite } \\
0.43 \Omega / 10 \mathrm{~W}\end{array}$ & 41800 & 812.4 & 24280 & $\begin{array}{l}\text { Vibration - } \\
\text { Permanent type }\end{array}$ & $\begin{array}{l}\text { Max. amplitude }-178 \\
\mu \mathrm{V}\end{array}$ & $\begin{array}{l}\text { Max. amplitude - } \\
1.2 \mathrm{deg} \\
\text { Duration - } 2.8 \mathrm{~s}\end{array}$ \\
\hline
\end{tabular}




\begin{tabular}{|l|l|l|l|l|l|l|}
\hline $\begin{array}{l}\text { Coil with ferrite } \\
0.43 \Omega / 10 \mathrm{~W}\end{array}$ & 44200 & 23.28 & 630.8 & $\begin{array}{l}\text { Involuntary } \\
\text { movement }- \\
\text { Single type }\end{array}$ & $\begin{array}{l}\text { Max. amplitude - 170 } \\
\mathrm{mV}\end{array}$ & $\begin{array}{l}\text { Max. amplitude - } \\
9.5 \mathrm{deg} \\
\text { Duration - 3.37 s }\end{array}$ \\
\hline $\begin{array}{l}\text { Resistor } 3.5 \Omega / \\
15 \mathrm{~W}\end{array}$ & 20000 & 78.32 & 178.9 & $\begin{array}{l}\text { Inductive } \\
\text { sensation }- \\
\text { Repelling type }\end{array}$ & $\begin{array}{l}\text { Max. amplitude - 97 } \\
\mu \mathrm{V}\end{array}$ & $\begin{array}{l}\text { Max. amplitude - } \\
2.4 \mathrm{deg} \\
\text { Duration }-1.3 \mathrm{~s}\end{array}$ \\
\hline $\begin{array}{l}\text { Transistor } \\
\text { D45H11 (PNP) }\end{array}$ & 87800 & 118 & 42.12 & Pain & $\begin{array}{l}\text { Max. amplitude }-0.95 \\
\mu \mathrm{V} \\
\text { Duration - } 1.78 \mathrm{~s}\end{array}$ & $\begin{array}{l}\text { Max. amplitude - } \\
8.1 \text { deg } \\
\text { Duration - 2.16 s }\end{array}$ \\
\hline
\end{tabular}

As was mention above, no matter, if they have or not have the sensations, the skin and sensitive nerves of the 194 examinate peoples responded of the same way to the EF and MF, emitted from the same electronic elements $(p<0.3)$. These responds were classified as the electrophysiology pattern of the skin sensations to the EF and MF.

For example, will present the electrophysiology patterns of the temperature sensations - warm and cold, permanent pricking sensation, vibration and pain sensation.

The electrophysiology pattern of the warm sensation

To receive the electrophysiology pattern of the warm sensation, the top of the second finger of the examinate person was placed on $1 \mathrm{~cm}$ from the electronic element Diod GP 30G, which emitted EF - $7.88 \mathrm{~V} / \mathrm{m}$ and MF - $0.13 \mathrm{nT}$. The recording 1 shows that at the moment of the increasing of the skin temperature (second channel) through the sensitive nerve (fourth channel) passes the specific group of the impulses, named the warm spindles. The warm spindle has 5-6 impulses with max. Amplitude $0.66 \mu \mathrm{V}$ and duration $-0.42 \mathrm{~s}$. Every time when the temperature of the skin rises up are formed the warm spindles, with existed or not existed sensation of the warm. See Record 1.

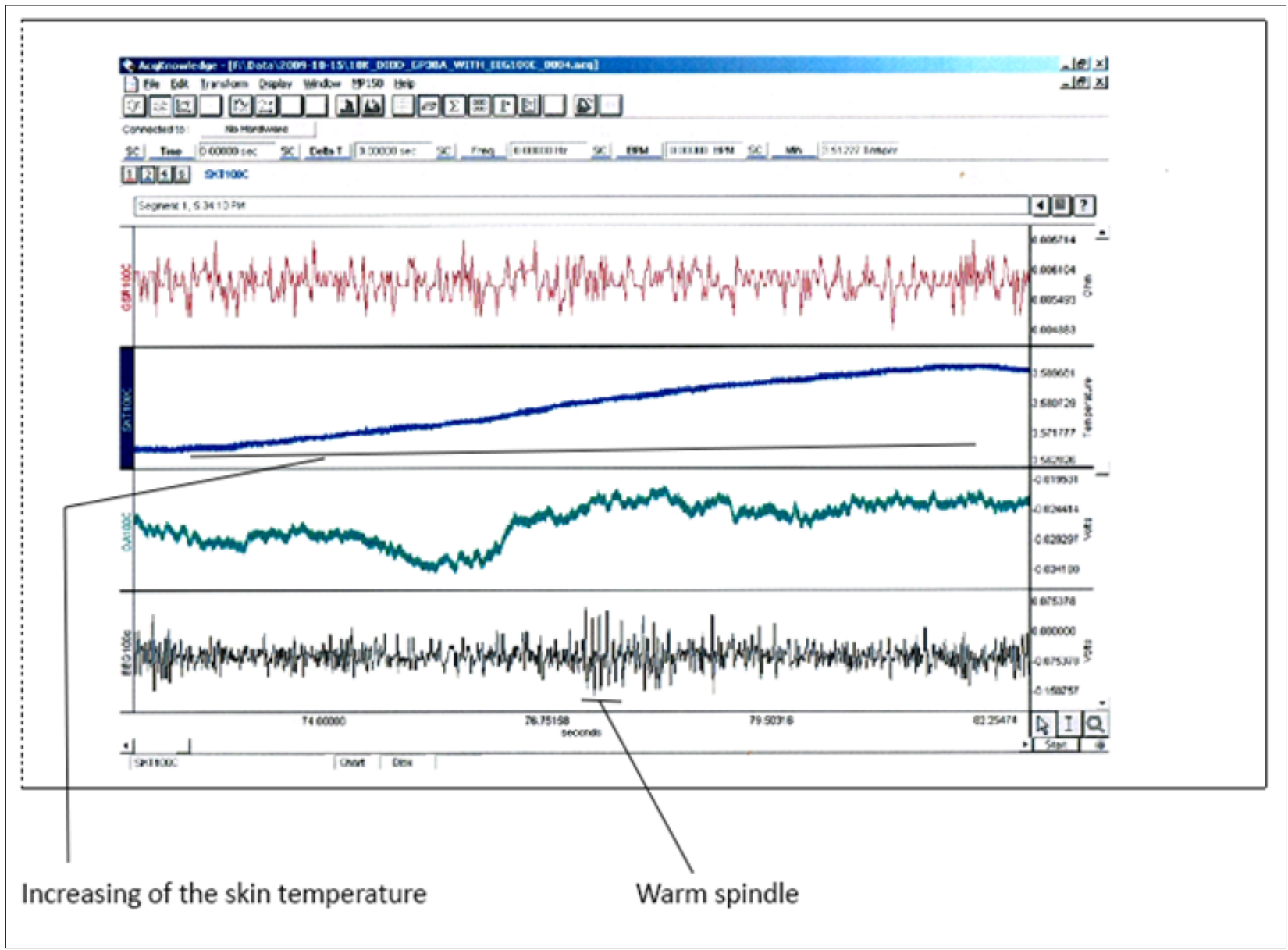

Record 1 
The electrophysiology pattern of the cold sensation

To receive the electrophysiology pattern of the cold sensation, the top of the second finger of the examinate person was placed on $1 \mathrm{~cm}$ from electronic element Cap $51 \mathrm{~F} / 630 \mathrm{~V}$, nonelectrolyte, which emitted EF - 9.28 V/m and MF - 0 nT. The recording 2 shows that at the moment of the decreasing of the skin temperature (second channel) through the sensitive nerve (fourth channel) passes the specific group of the impulses, named the cold spindle. The cold spindle is the group of the 5-7 impulses with amplitude $-0.18 \mu \mathrm{V}$; Duration $-0.25 \mathrm{~s}$. Every time when the temperature of the skin decreases is formed the cold spindle, with existed or not existed sensation of the cold. See Record 2.

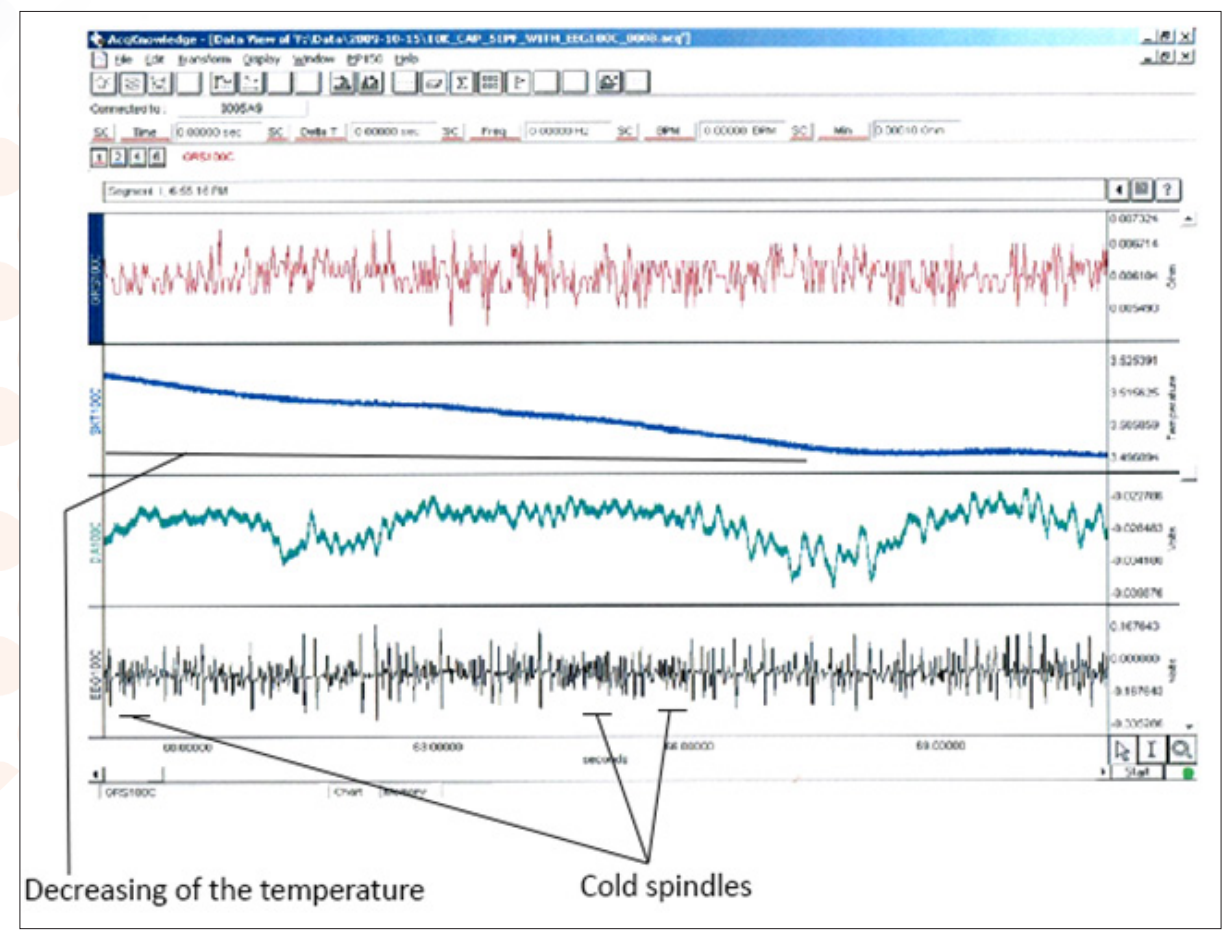

Record 2

The cold spindles have the different shape at the beginning of decreasing of the temperature and at the end, when the temperature is stabilized. See Record 3.

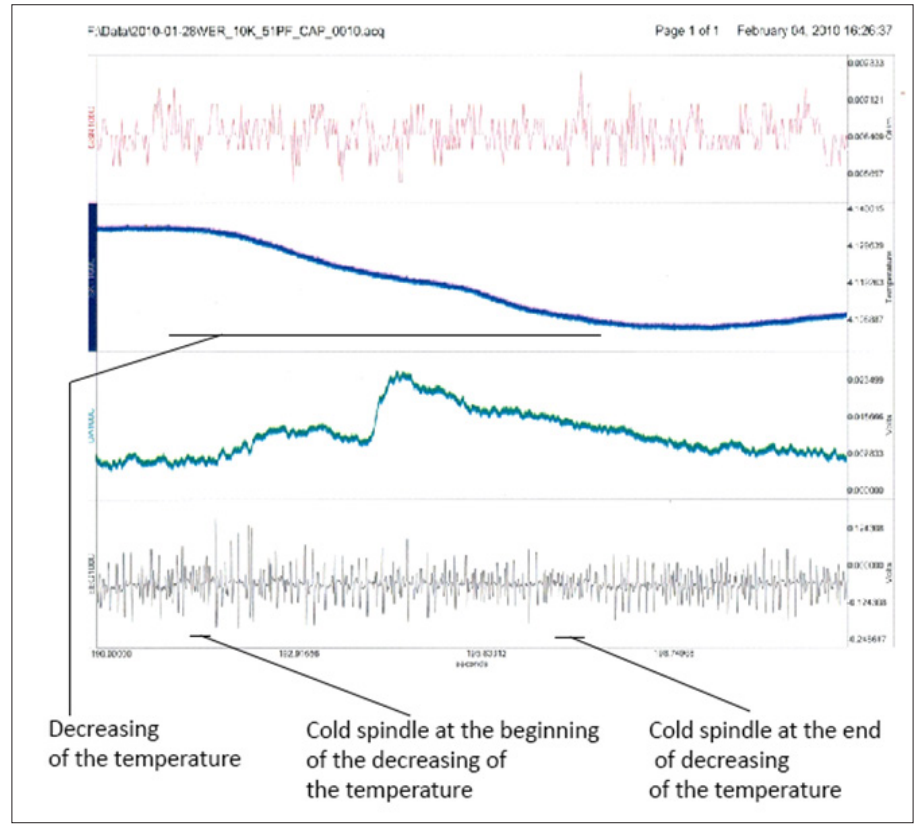

Record 3 
The electrophysiology pattern of the pain

To receive the electrophysiology pattern of the pain sensation, the top of the second finger of the examinate person was placed on $1 \mathrm{~cm}$ from the electronic element Transistor D45H11 (PNP), which emitted EF - $118 \mathrm{~V} / \mathrm{m}$ and MF - $42.12 \mathrm{nT}$. At the recording 4 can be seen that at the moment before to be filled the pain is formed one high amplitude impulse, which is followed from decreased to absent activity of the sensitive nerve (fourth channel). The filling of the pain from the examinate person continues at the period of the absent activity in the sensitive nerve, when the maximal amplitude of the impulses is $0.95 \mu \mathrm{V}$ and duration of the pain sensation is $1.78 \mathrm{~s}$. same moment the skin temperature decrease (second channel). At the third channel can be seen very small movement of the second finger (goniometry at the third channel) with forming of the group of the impulses with higher amplitude at the same moment in the sensitive nerve (fourth channel) and consequent period of significantly deceasing of the amplitude of the impulses - period of the pain. All these changes form the electrophysiology pattern of the pain sensation to the EF and MF. The reaction of the skin to applied EF and MF and activity of the peripheral sensitive nerve is same in the all examinate persons, no matter if they feel of not fell the pain. See Record 4.

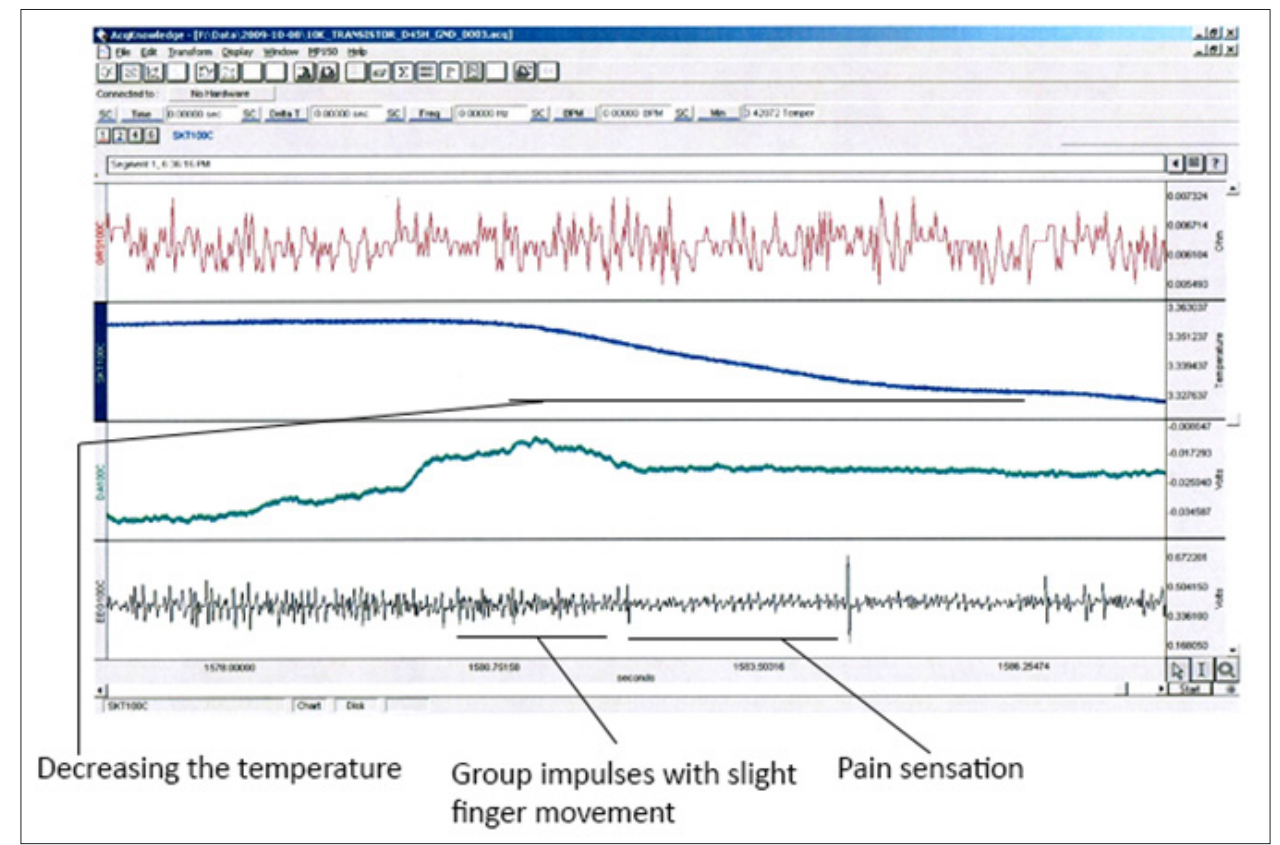

Record 4

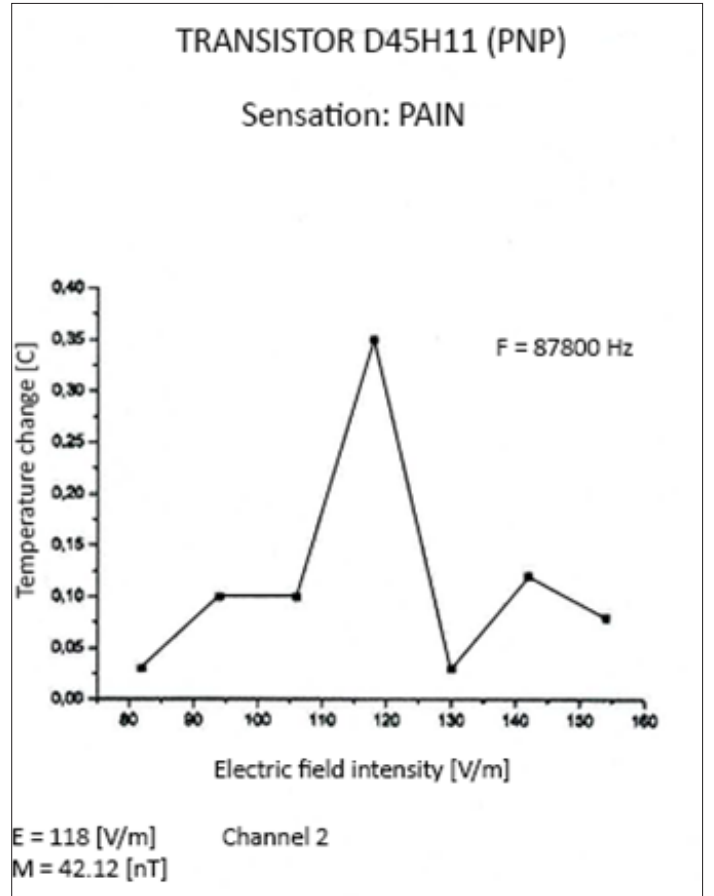

Graphic 1
The Graphic 1 shows the temperature changes at the channel 2 from the electrophysiology pattern of the pain. When the electric field reaches $118 \mathrm{~V} / \mathrm{m}$ the temperature decreases at the interval of the pain sensation.

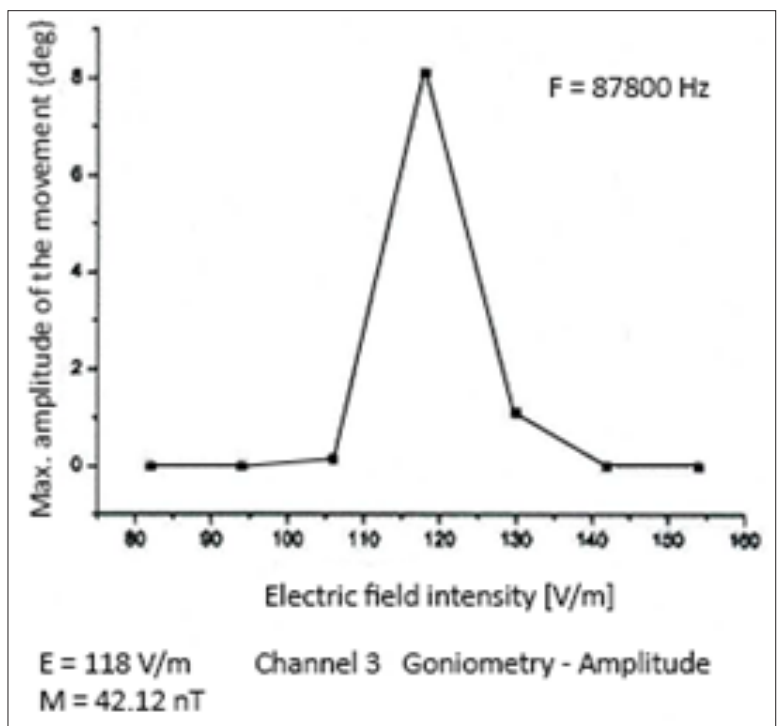

Graphic 2 


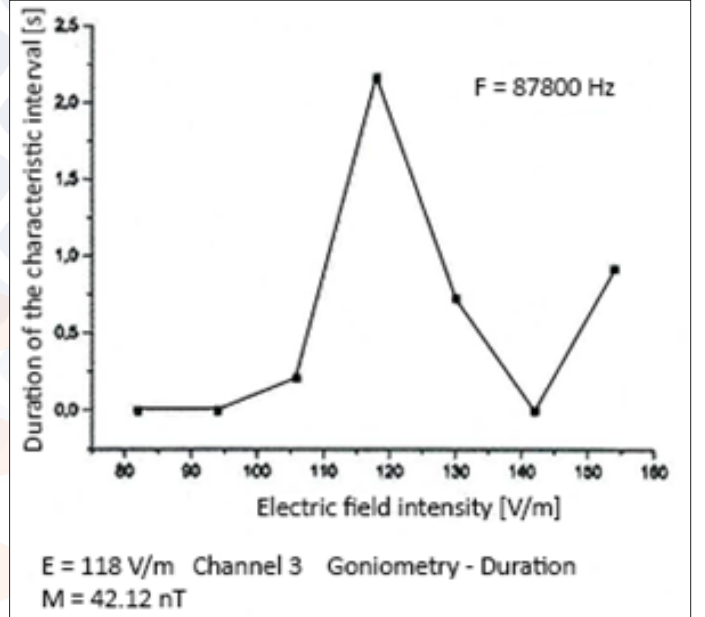

Graphic 3

The Graphics 2 and 3 show the goniometry changes at the channel 3 from the electrophysiology pattern of the pain. When the electronic element is emitting electric field $118 \mathrm{~V} / \mathrm{m}$ and magnetic field $42.12 \mathrm{nT}$, on $1 \mathrm{~cm}$ distance from the top of the skin of the second finger, the goniometer registries the finger involuntary movement with the max. Amplitude $8.2 \mathrm{deg}$ (Graphic 2; $1 \mathrm{deg}-1 \mathrm{~mm}$ ) and duration of the movement 2.25 s (Graphic 3).

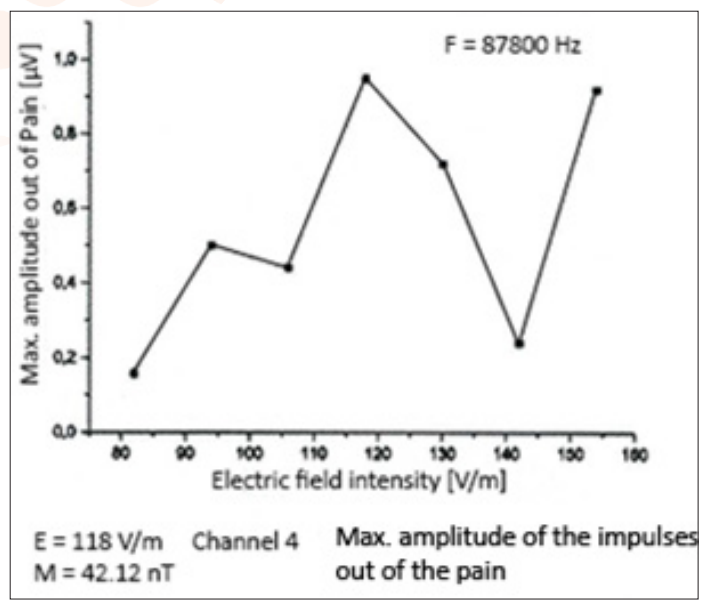

Graphic 4

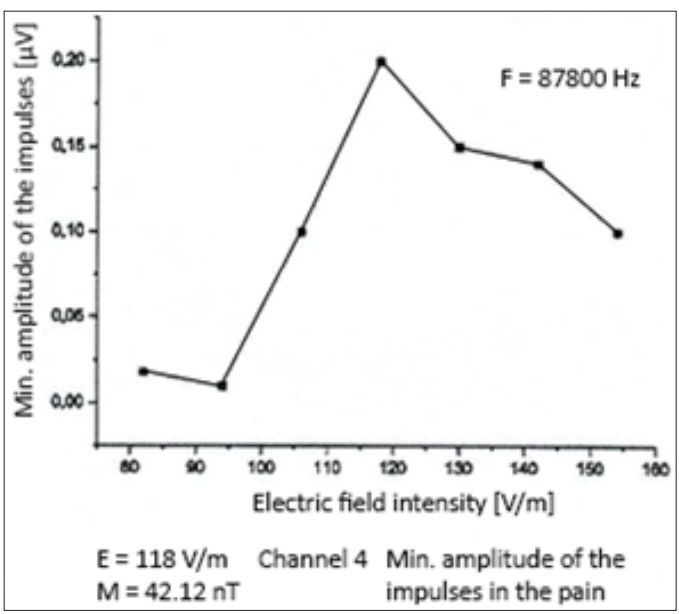

Graphic 5
The Graphic 4 and Graphic 5 show the sensitive nerve activity at the channel 4 from the electrophysiology pattern of the pain. When the electronic element is emitting electric field $118 \mathrm{~V} / \mathrm{m}$ and magnetic field $42.12 \mathrm{nT}$, on $1 \mathrm{~cm}$ distance from the top of the skin of the second finger, the maximal amplitude of the impulses, which are transported through the sensitive nerve, out of the period of the pain are $0.95 \mu \mathrm{V}$ (Graphic 4) and at the moment of the pain are with min. amplitude $0.20 \mu \mathrm{V}$ (Graphic $5)$.



Graphic 6

The Graphic 6 shows the duration of the pain period $-1.78 \mathrm{~s}$ at the channel 4 from the electrophysiology pattern of the pain. The maximal duration of the pain interval was recorded, when the electronic element Transistor D45H11 (PNP) emitted the electric field $118 \mathrm{~V} / \mathrm{m}$ and magnetic field $42.12 \mathrm{nT}$.

The same graphics are made for all used electronic elements and kind sensations.

Same electrophysiology pattern of the pain sensation can be seen and from the EF and MF emitted from another electron element Cap 51 F/630 V, nonelectrolyte. The EF on $1 \mathrm{~cm}$ from the electronic element was measured 306.6 V/m and MF -2.48 nT. See Record 5. 


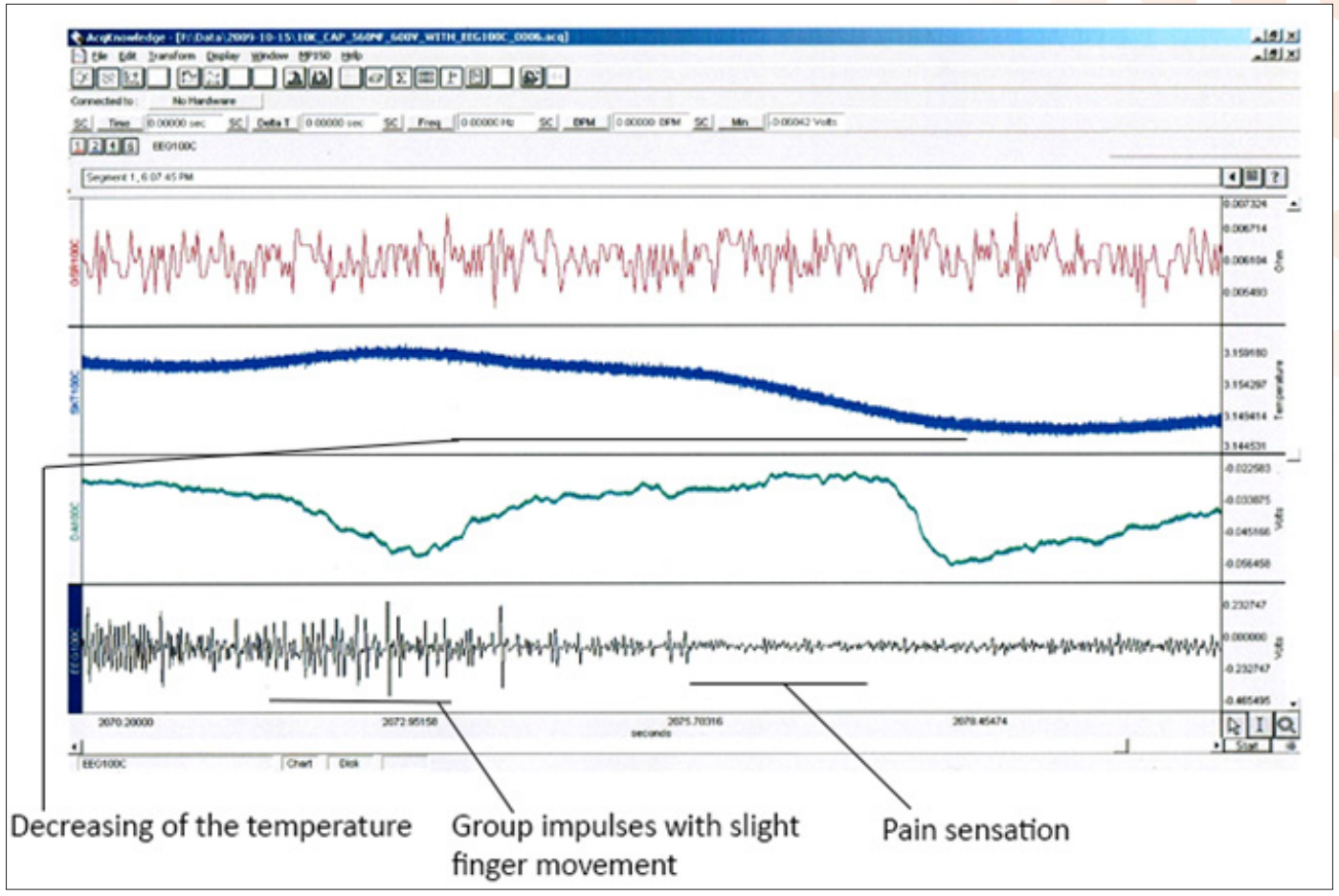

Record 5

The electrophysiology pattern of the pricking sensation - permanent type

To receive the electrophysiology pattern of the pricking sensation - permanent type, the top of the second finger of the examinate person was placed on $1 \mathrm{~cm}$ from the electronic element Diod GP 30G, which emitted EF - 7.36 V/m and MF - 0.128 nT, calibration $-45030 \mathrm{~Hz}$. At the recording 6 can be seen that at the moment of the decreasing of the skin temperature (second channel) through the sensitive nerve (fourth channel) permanently are passing the impulses - period when the examinate persons fell the permanent pricking sensation. The impulses are with max. Amplitude $1.28 \mu \mathrm{V}$. Every time when the skin of examinate person was exposed to the EF and MF from the electronic element Diod GP 30G, was recorded the same changes at the skin temperature, goniometric changes and peripheral sensitive nerve activity, with existed or not existed sensation of the pricking sensation. See Record 6.

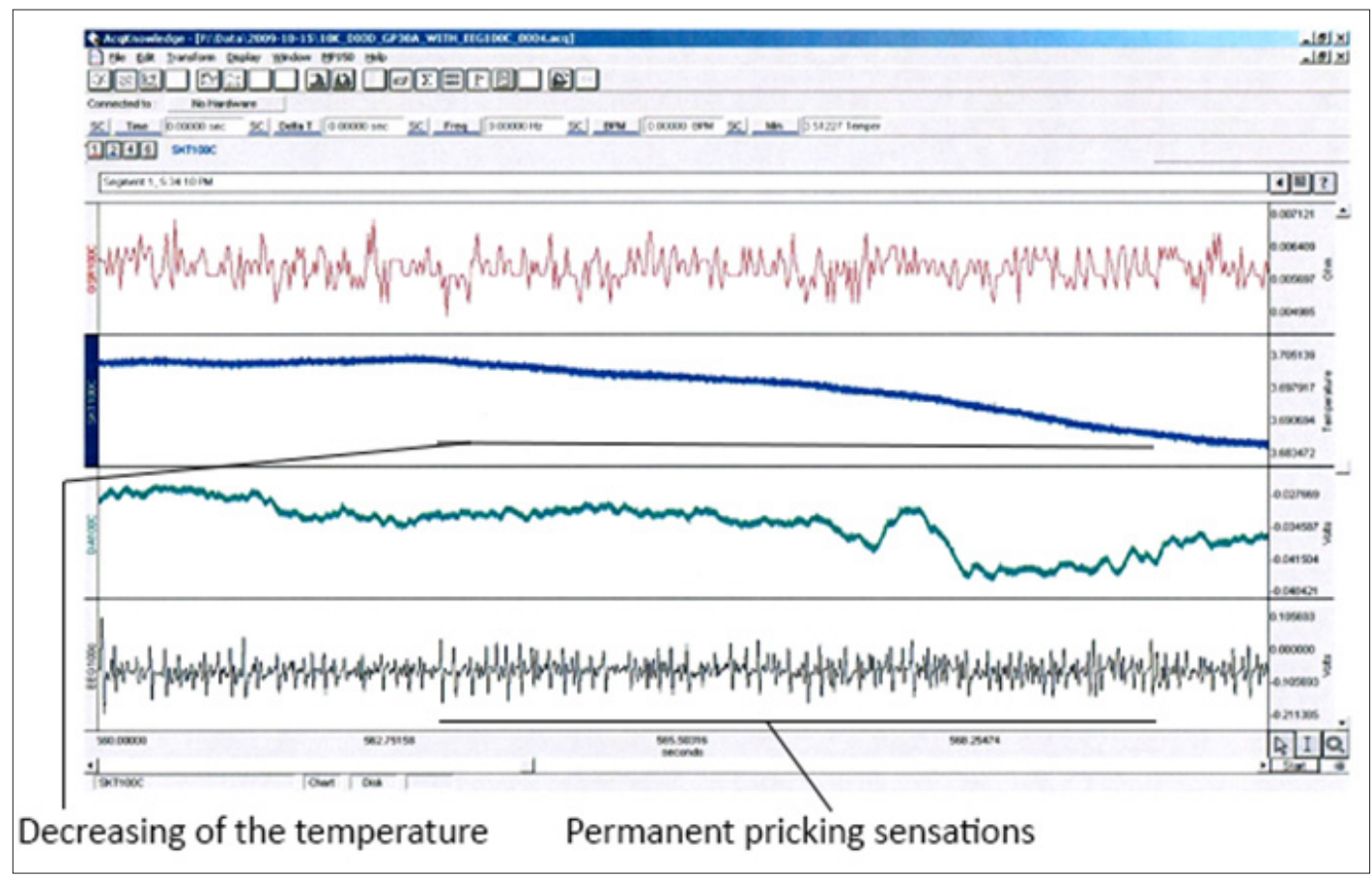

Record 6 
The electrophysiology pattern of the vibrations

To receive the electrophysiology pattern of the involuntary movement vibration - permanent type, the top of the second finger of the examinate person was placed on $1 \mathrm{~cm}$ from the electronic element Coil with ferrite $\mathbf{0 . 4 3} \boldsymbol{\Omega} / \mathbf{1 0 W}$, which emitted EF $812.4 \mathrm{~V} / \mathrm{m}$ and MF - $24280 \mathrm{nT}$, calibration $-41800 \mathrm{~Hz}$. At the recording 7 can be seen that at the moment of the increasing of the skin temperature (second channel) through the sensitive nerve (fourth channel) are passing the single impulses with maximal amplitude - $178 \mu \mathrm{V}$. After every bigger single impulse has the involuntary movement - vibration movement at the second finger, which were recorded at the third channel. The vibrations were with maximal amplitude $1.2 \mathrm{deg}$. and maximal duration $2.8 \mathrm{~s}$. Every time when the skin of examinate person was exposed to the EF and MF from the electronic element Coil with ferrite 0.43 $\Omega / 10 \mathrm{~W}$, was recorded the same changes at the skin temperature, goniometric changes and peripheral sensitive nerve activity, with existed or not existed sensation of the vibration. See Record 7.

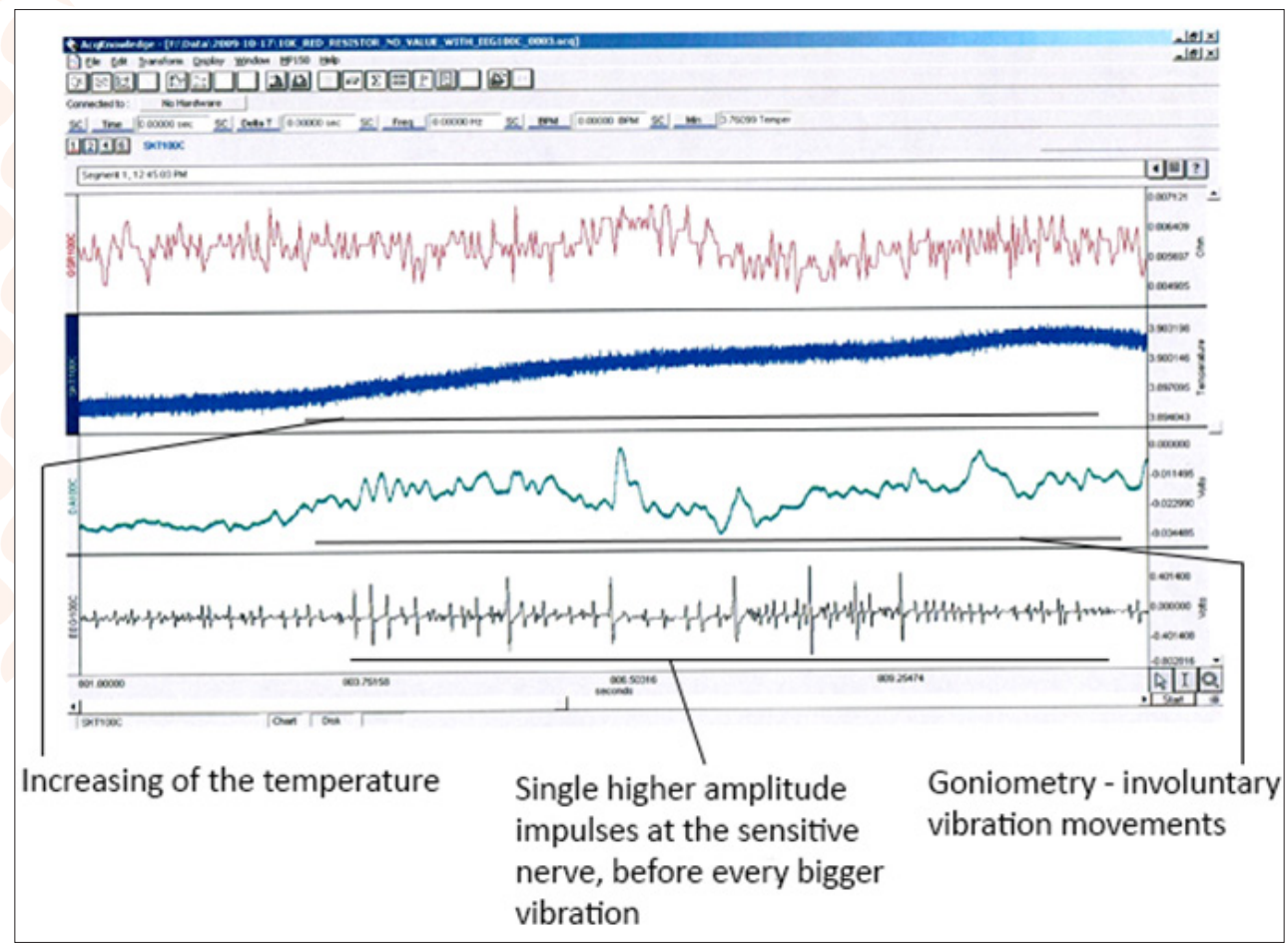

Record 7

\section{Analyses}

The changes of the electrophysiologic parameters as the skin conductivity, temperature, involuntary muscle contraction and skin nerve activity show that the human skin receptors are sensitive to the very small EF and MF. The fact that small number of the examinate peoples have sensations to the EF and MF, but their skin and sensitive nerve respond at same way in all of the examinate peoples can be explained with the filtration of the information from the peripheral sensitive nerve at the level of the sensitive nucleus of the thalamus (ventral posterolateral nucleus and intralaminar nucleuses of the thalamus). This way the sensitive information is not rich the somatosensorial analyzer at the brain cortex.

The different kind sensations can be induced from one electronic element with different calibration. The maximal intensity of the sensation is not induced with the maximal working regime of the elements. There is the specific frequency of the element calibration to induce the specific sensation with the specific changes in the electrophysiology condition of the skin and peripheral sensitive nerve. The EF is able to induce the more the thermal sensations - warm and cold, pricking sensation, pressing sensation and less the involuntary movement as vibration - single type. The MF is able more to induce the involuntary movement - single and permanent type, vibration - permanent type, inductive sensation - repelling type and less pricking sensation - single type. EF and MF together, in balancing proportion, are able to induce the involuntary movement - single and permanent type, inductive sensation - attractive and repelling type, vibration - permanent type and pain. See Table 3. 


\begin{tabular}{|c|c|}
\hline Field & TYPE SENSATIONS \\
\hline $\begin{array}{l}\text { ELECTRIC } \\
\text { FIELD }\end{array}$ & $\begin{array}{l}\text { Thermal sensation - cold and warm type } \\
\text { Pricking sensation - permanent type } \\
\text { Pain sensation } \\
\text { Pressing sensation } \\
\text { Vibration - single type }\end{array}$ \\
\hline $\begin{array}{l}\text { MAGNETIC } \\
\text { FIELD }\end{array}$ & $\begin{array}{l}\text { Involuntary movement }- \text { single and } \\
\text { permanently type } \\
\text { Vibration - permanent type } \\
\text { Inductive sensation - repelling type } \\
\text { Pricking sensation - single type }\end{array}$ \\
\hline $\begin{array}{l}\text { ELECTRIC } \\
\text { AND } \\
\text { MAGNETIC } \\
\text { EIELD }\end{array}$ & $\begin{array}{l}\text { Involuntary movement }- \text { single }(\mathrm{MF}>\mathrm{EF}) \\
\text { and permanent type }(\mathrm{MF}>\text { or }=\mathrm{EF}) \\
\text { Inductive sensation }- \text { attractive type } \\
(\mathrm{MF}=\mathrm{EF}) \text { and repelling type }(\mathrm{MF}>\text { or }<\mathrm{EF}) \\
\text { Vibration }- \text { permanent type }(\mathrm{MF}>\mathrm{EF}) \\
\text { Pain sensation }(\mathrm{EF}>\mathrm{MF})\end{array}$ \\
\hline
\end{tabular}

The electric field activates

- The receptors of warm and receptor of cold - free nerve endings type $\mathrm{A} \delta$ and type $\mathrm{C}$ to induce the thermal sensation - warm and cold.

- The Meisner`s corpuscles, Iggo domen complex, Merkel`s discs and free nerve endings to induce the pricking sensation - permanent type.

- The Pacinian corpuscles, Merkel`s discs, Ruffini`s nerve endings and free nerve endings to induce the pressing sensation.

- $\quad$ The Free nerve endings type A $\beta, A \Upsilon$ and $C$ to induce the pain sensation.

- The Pacinian corpuscles, Meisner's corpuscles, Iggo domen complex, Merkel`s discs and free nerve endings to induce the vibration sensation - single type.

\section{The magnetic field activates}

- The muscle spindles, Golgi tendon receptors, Ruffini`s nerve endings, Pacinian corpuscles and free nerve endings to induce the involuntary movements - single and permanent type, vibration - permanent type, inductive sensation - repelling type, pricking sensation - single type.

The analyze of the experimental result shows the electric field more influence the specialized skin receptors for temperature, touching, pressing, vibration and pain, whereas the magnetic field influences more the receptors of the proprioception for the pose and movement. This is why is not found the specific receptor for magnetic field at the skin and still existing the opinion that the skin and human body is not sensitive to the magnetic field.

\section{Conclusions}

- The human skin is able to react with the specific electrophysiologic changes to the electric field and magnetic field - electrophysiology patterns of sensation to EF and MF. The electrophysiology change can be detected in every one person, no matter if he has not the sensations (electro hypersensitivity). The electrophysiology patterns of the sensations show how the specialized receptors in the skin and receptors of proprioception transformed the stimulus of the EF and MF in the specific groups of the impulses, to be translate to the central nerve system. The warm and cold spindles show how the skin receptors for warm and cold code the temperature information to be delivered through the sensitive nerves to the brain.

- The sensitive nucleus of the thalamus filtrates the sensitive information at most of the people.

- The electric field more influence the specialized skin receptors for temperature, touching, pressing, vibration and pain, whereas the magnetic field influences more the receptors of the proprioception.

- The receptors for magnetic field are the free nerve endings, receptors of proprioception and receptors for touch.

- The persons with the hypersensitivity to the EF and MF insist to reconsider the neurologic terminus as the paresthesia, spontaneous and projection pain, phantom pain (result of the decreased threshold of the skin receptors to $\mathrm{EF}$ and $\mathrm{MF}$, at the cutting place).

- The full classification of the sensations to the EF and MF (7 major kind) and their electrophysiology patterns can be used in the medicine practice to verify the contradictory electro hypersensitivity. [4] Very small precent of the population reports the unpleasure symptoms to the EF and MF. This was confirmed from our study - only $2 \%$ has had the sensations to the EF and MF from the electronic elements, but the skin receptors and peripheral sensitive nerve were responded at all examinate persons - all have perception but few have sensation. The filtration of the skin sensations (transported by the spinothalamocortical pathway) at sensitive nucleus of the thalamus (ventral posterolateral nucleus and intralaminar nucleuses of the thalamus) do not mean that brain functions are not change - undifferentiated skin sensations, unpleasure feeling, mood changes, easy tiredness. The electro hypersensitivity has to be very precisely reexamined and recognized as all other disease with the environment etiology.

- Additional research must to be done to confirm the safety of the existed norms for the environmental EF and MF.

\section{Business Opportunity}

The decoding of the sensations to the electrical and magnetic fields can be interesting for:

- The robotic industry - anthropomorphic and industrial robots.

- The medicine - diagnostic devices on the base of the electronic skin to detected and analyzed the physical field of the human body. 
References

1. Guyton \& Hall's Textbook of Medical Physiology. Eleventh edition. 2005. Publisher - Elsevier. ISBN-10 0721602401, ISBN-13 978072160240

2. Kandel Eric R., Schwartz James H., Jessell Thomas M., Siegelbaum Steven A., Hudspeth A.J (2013) Principles of Neural Science. Fifth edition. 2013. McGraw-Hill. ISBN 978-0-07-139011-8

3. https://www.biopac.com/product/mp150-dataacquisition-systems/

4. https://en.wikipedia.org/wiki/Electromagnetic hypersensitivity

Copyright: (C2021 George Zdravkov. This is an open-access article distributed under the terms of the Creative Commons Attribution License, which permits unrestricted use, distribution, and reproduction in anymedium, provided the original author and source are credited. 